\title{
GLOCALIZATION FOR SUSTAINABLE DEVELOPMENT
}

\author{
Ketut Silvanita Mangani \\ Dept.of Magister Management, Universitas Kristen Indonesia \\ Email: ktut.silvanita@uki.ac.id
}

\begin{abstract}
Abstrak
Esai ini mengkaji konsep mana: globalisasi atau glokalisasi yang lebih berkontribusi pada pembangunan berkelanjutan di abad XXI. Pengertian globalisasi adalah internasionalisasi ekonomi sebagai proses deterministik dari universalisasi yang bersifat top-down. Beberapa ahli menjelaskan bahwa proses globalisasi memiliki dampak yang luas. Oleh karena itu, agar globalisasi semakin meluas dan meminimalkan dampak negatifnya, proses top-down dalam globalisasi perlu dipadukan dengan proses bottom-up, yaitu dengan memperhatikan konteks lokalnya, atau disebut glokalisasi. Dapat disimpulkan bahwa glokalisasi akan lebih dapat diterima dan berkelanjutan.
\end{abstract}

Kata Kunci: Globalisasi, Glokalisasi, Konten lokal, Pembangunan berkelanjutan

\section{Abstract}

This essay examines which concept: globalization or glocalization is contributing more to sustainable development in the XXI century. Globalization is a notion of economic internationalization as a deterministic process of top-down universalization. Some scholars explained that the process of globalization contains widely impact. Therefore, for globalization to become more widespread and to minimize its negative impacts, the top-down process in globalization needs to be combined with the bottom-up process, i.e. by taking into account the local context, or so-called glocalization. We conclude that glocalization will be more acceptable and sustainable.

Keywords: Globalization, Glocalization, Local content, Sustainable Development

\section{A. INTRODUCTION}

Stiglitz (2002) as cited in Jovane (2015) defines globalization as the "closer integration of the countries and peoples of the world brought about by the enormous reduction of costs of transportation and communication, and the breaking down of artificial barriers to the flows of goods, services, capital, knowledge, and people across borders". Globalization provides an opportunity to increase production and economic growth to countries involved in it. Using panel data for 123 countries in 1970-2000, Empirically, Dreher (2006) analyzes the globalization index as well as the sub-index to measure a single dimension that affects economic growth. The result of his research shows that globalization drives economic growth.

Globalization is much more than just trade. In the past, globalization has often focused more on the economic side, such as trade, foreign direct investment and international capital flows. However, now the term globalization has expanded to cover broader fields and activities such as culture, media, technology, socio-culture, politics, and even biological 
factors, such as climate change. Therefore, the definition of globalization becomes more widespread and open, depending on the context in which will be explained.

The term of glocalization first appeared in a late 1980s publication of the Harvard Business Review (as cited from Wikipedia). According to Sun et al. (2017), the expressions of glocalization vary from country to country, indicating a high degree of flexibility in translating and applying international standards at the local level. The local content is important and becomes the key in organizing and intervening in socio-economic life, which related to institutional interpretations of economic activities, industrial strategies, conditions of breadwinners and spatial development patterns.

Sustainable development has been defined in many ways, but the most frequently quoted definition is known as the Brundtland Report (WWW 1): "Sustainable development is development that meets the needs of the present without compromising the ability of future generations to meet their own needs. It contains within it two key concepts:

1. The concept of needs, in particular the essential needs of the world's poor, to which overriding priority should be given; and

2. The idea of limitations imposed by the state of technology and social organization on the environment's ability to meet present and future needs."

This essay examines which concept: globalization or glocalization is contributing more to sustainable development in XXI century.

\section{B. GLOBALIZATION AND GLOCALIZATION}

In the context of sustainable development in the XXI century, there might be different results between the practice of globalization and glocalization. The term globalization is not new. The World Bank notes that poor countries with a population of around 3 billion have entered the global market. When in the previous 20 years, most of the exports from developing countries were primary commodities, now manufacturing and services have dominated their export products. The successful integration has supported poverty alleviation. But it could be even more effective (World Bank, 2002). Globalization makes the world "colorful." The companies that have been established in their country expand their business to other countries to get more profits. In other words, the products and services in one country can be sold/enjoyed by people in other countries. For example, KFC products from America are grown in various countries in the world. However, Prakash (2011) stated that in order to operate successfully in their host countries, the multinational food enterprises must adopt glocalized strategies in marketing, product development, advertisement etc.

The term of glocalization for the first time appeared in the late 1980s from the publication of the Harvard Business Review. Drori, et al. (as cited in Pastuh, 2015) explain that glocalization wants to avoid a notion of economic internationalization as a deterministic process of top-down universalization. This essay argues that glocalization will contribute more to sustainable development in the XXI century than globalization. In general, people do not like with the process of top-down universalization as in the practice of globalization. It argued that glocalization would be more readily accepted because it corresponds to the customs practised in their country or region in terms of culture, media, technology, sociocultural, political, and even biology and therefore it would be sustained. 
Stiglitz (as cited in Jovane, 2015) defines globalization as the "closer integration of the countries and peoples of the world brought about by the enormous reduction of costs of transportation and communication, and the breaking down of artificial barriers to the flows of goods, services, capital, knowledge, and people across borders." However, the definition of globalization is becoming more widespread and open depends on the context. Financial Times explained that term globalization has expanded to include a broader range of areas and activities such as culture, media, technology, socio-cultural, political, and even biological factors, e.g. climate change. Drori, et al. (as cited in Pastuh, 2015) stated that globalization is a notion of economic internationalization as a deterministic process of top-down universalization. However, according to Naomi Klein (2000) in her book 'No Logo,' universalization process of globalization contains a wide impact. She explains that "as more people discover the brand-name secrets of the global logo web, then their outrage will fuel the next big political movement, a vast wave of opposition squarely targeting transnational corporations, particularly those with very high name-brand recognition." She discovered that behind the high name-brand, there is an exploitation of the people in developing countries. Crook, C. et al. (2003) notes seven main worries about globalization. First, there is a fear that the wages of low-skilled workers will fall in a market that experiences cheap imports. Second, increasing economic insecurity for almost everyone due to accelerating economic changes. Third, the existing subsidy (income support) pattern will become more explicit, making it difficult to sustain. Fourth, there will be "unbalanced growth," so that poverty in developing countries will get worse. Fifth, social spending will decrease because of the pressure caused by "international competition." Sixth, the environmental standards will be under pressure. Seventh, that most international trade is "unfair" because of exploitation. However, the fourth to seventh fears may be misconceived, but the first to third fears, based on reality.

Another example of the negative impact of globalization without regard to the local aspect is the disruption of the sustainability of the traditional Thai lifestyle (Panitchpakdi, 2012). Srisakara (as cited in Panitchpakdi, 2012), explained that "This globalization is changing new generations of people into individuals who live without human mentality of the past, without social contacts, without relationships with clans, environment and supernatural beings, and, most importantly, without any conviction that they have to live with one another as social groups. All their geo-cultures, bio-cultures and cultural lives have been destroyed." Panitchpakdi (2012) suggested some factors that have helped the Kao Yi Sarn community sustain its localization amidst the globalization in a rather balanced manner. He argued that holistic development ensures the balanced globalization- localization relationships.

According to Roland Robertson (as cited in Wikipedia), glocalization means the simultaneity - the co-presence - of both universalizing and particularizing tendencies. Drori, et al. (as cited in Pastuh, 2015) explained that glocalization wants to avoid a notion of economic internationalization as a deterministic process of top-down universalization. Instead, as an "assault on binary thinking", the global and the local are seen as phenomena in a complex, pluralistic and dialectic relationship; "glocalization [...] suggests that the global and the local are mutually constitutive: the so-called global is a collage of local practices, behaviors and tastes, while the so-called local is increasingly constructed within the scripts drafted by global forces". 
One example of glocalization practice is glocalization of Responsible Investment or RI from the US to France and Que'bec (Gond \& Boxenbaum, 2013). The results show how individuals adapt RI practices to the context in their respective countries using the contextualization process - filtering, repurposing, and merging. By doing so, they reformed the RI at the political, cultural and technical levels. The results explained that RI which was applied with different versions of glocalization was developed and adapted through contextualization works. Study by Prakash (2011) explained that multinational enterprises, when deciding to expand their operations to a new country, have to make a choice between following uniform business strategies as in their home country or modify their strategies to suit the host country socioeconomic and political environment. He pointed out that, in order to operate successfully in their host countries, the multinational food enterprises must adopt Glocalized strategies in marketing, product development, advertisement etc. (Prakash, 2011). In the context of glocalization, it is important to bring local content into detailed examination because local content is a factor that intervenes in socio-economic life. (Sun, Chao, Woo \& $\mathrm{Au}, 2017)$.

\section{CONCLUSION}

Global economic integration has supported poverty reduction and should not be reversed. Because the top-down approach, universalization in globalization can bring negative impact. Therefore, in order for globalization to become more widespread and to minimize its negative impacts, the top-down process in globalization needs to be combined with the bottom-up process, i.e. by taking into account the local context, or so-called glocalization. It can be concluded that glocalization will be more acceptable and sustainable.

\section{DAFTAR PUSTAKA}

Collier, P., \& Dollar, D. (Eds.). (2002). Globalization, growth, and poverty: Building an inclusive world economy. World Bank Publications.

Crook, C., Paolera, G. D., Ferguson, N., Krueger, A. O., \& Rogowski, R. (2003). Globalization in Interdisciplinary Perspective. A Panel. In Globalization in Historical Perspective (pp. 549-570). University of Chicago Press.

Dreher, A. (2006). Does globalization affect growth? Evidence from a new index of globalization. Applied economics, 38(10), 1091-1110.

Gond, J. P., \& Boxenbaum, E. (2013). The glocalization of responsible investment: Contextualization work in France and Quebec. Journal of business ethics, 115(4), 707721.

Klein, N., \& Sawchuk, K. (2000). No logo: taking aim at the brand bullies. Canadian Journal of Communication, 25(4), 576.

Pastuh, D. (2015). Global Themes and Local Variations in Organization and ManagementPerspectives on Glocalization, Gili S. Drori, Markus A. Höllerer, Peter Walgenbach (Eds.), Routledge, New York/London (2014), xv+ 432 pp., 78, 95\$(paperback), ISBN: 978-0-415-80768-5.

Prakash, A., \& Singh, V. B. (2011). Glocalization in food business: strategies of adaptation to local needs and demands. Asian Journal of Technology \& Management Research, 1(1).

Stiglitz, J. E. (2002). Globalization and its Discontents (Vol. 500). Norton: New York. 
ARTIKEL

Sun, Y., Chao, T. Y., Woo, J., \& Au, D. W. (2017). An institutional perspective of "Glocalization" in two Asian tigers: The "Structure- Agent- Strategy" of building an age-friendly city. Habitat International, 59, 101-109.

www. http://www.iisd.org/topic/sustainable-development, electronic document 